\title{
Infestation of Rice Weevils in Rice Grain in Relation to Drying Procedures after Harvest and the Form of the Grain at Different Stages in the Milling Process*
}

\author{
Fumiki Takahashi and Hiroyuki Mizuno \\ Department of Environmental Studies, Faculty of Integrated Arts \\ and Sciences, Hiroshima University, Hiroshima 730, Japan
}

(Received October 9, 1981)

\begin{abstract}
Drying conditions after harvest and the form of the rice grain at different stages in the milling process affect the degree of infestation by pest insects. The reproduction and development of two rice weevils, Sitophilus zeamais and S. oryzae, were compared from life tables obtained at $30^{\circ} \mathrm{C}$ and $70 \%$ R.H. on rice grain at different stages in its processing (rough, hulled, or polished rice) and under different drying conditions for rough rice (naturally dried by hanging on racks or mechanically dried with heated air).

No progeny were found on rough rice dried naturally. Weevils were able, however, to deposit eggs into a split in the husk of rough rice that was produced by mechanical drying. The average length of the developmental period was shortest on hulled rice, polished rice probably being inferior to hulled rice in its content of nutrients. The longevity and oviposition period of adult weevils were longest on polished rice and shortest on rough rice. The reproductive potential changed with adult aging. The peak of natality $\left(b_{x}\right)$ curve came earlier on hulled rice than on polished rice. The reproductive potential during the adult life span was highest on hulled rice and smallest on rough rice.

Our results are evidence that rough rice is the most desirable form in which to store rice grain to prevent its infestation by rice weevils.
\end{abstract}

\section{INTRODUCTION}

Temperatures below $15^{\circ} \mathrm{C}$ are supposed to prevent the growth and development of insects in stored agricultural products. But, as air-conditioning is expensive and consumes much fossil fuel, we must find a more economical storage system by reexamining conventional methods of storage with respect to the social, agricultural, and climatic conditions of each locality.

Rice, the most important cereal grain used in Japanese foods, contains 20-25\% water at harvest. Desiccation to give rice grain that has a water content of less than $13-15 \%$ before storage is needed, otherwise, the grain will be damaged easily by

* This study was supported by Grants-in-Aid No. 411913 and No. 511011 from the Japanese Ministry of Education, Science and Culture for the Special Project Research, "A comparative agricultural study of biological production in tropical and temperate regions." This paper was presented at the 16th International Congress of Entomology, Kyoto, August 3-9, 1980, Section 10, Symposium on Stored Product Entomology and Structural Insects. 
insects and microorganisms during storage. In Japan it has been a conventional practice to hang the ears of rice attached to their straw on racks set in paddy fields for a few weeks in order to dry the grain with natural air currents (Plate 1). Recently, the drying of rice by heated air in mechanical dryers (Plate 2) has become popular. Farmers are introducing combine machines inspite of the expense because they are want to simplify rice cultivation procedures and to save time (Plate 3). As a result, they dry grain mechanically with heated air and sell it to the government in the form of hulled rice as soon as possible. Some farmers, however, keep the traditional style of harvesting and store the rice grain as rough rice in storage sheds for their own food.

Takahashi $^{1)}$ reported many years ago that the storage of rough rice is a good way to protect the grain from the rice weevils, Sitophilus spp. Governmental and commercial grain handlers, however, usually store rice hulled because rough rice occupies more storage space (about twice the space needed for hulled grain). Therefore, rough rice is not a common form of rice grain for trade in Japan. In some local districts, rice grain recently has been kept unhulled for a period in elevator system.

The adult life table of Sitophilus zeamais and S. oryzae on wheat and maize grains at $29.1^{\circ} \mathrm{C}$ and $32.3^{\circ} \mathrm{C}$ were analysed by Birch. ${ }^{2)}$ In our study we examined adult longevity, developmental speed, and the birth rates of S. oryzae and S. zeamais reared on the rice from different stages during the processing of the grain. Experiments were conducted to obtain the life tables and to examine the effect of mechanical drying with heated air on the life performance of the weevils.

\section{MATERIALS AND METHODS}

The strains of S. oryzae and S. zeamais used were obtained from Prof. T. Yoshida of Okayama University. The insects were reared at $30^{\circ} \mathrm{C}, 70 \%$ R.H. The grain used as food for the weevils was the Nakate-Shinsenbon variety of Oryza sativa japonica, produced at Hiroshima Agricultural College. The forms of grain used were rough (paddy), hulled (brown), and polished (milled). For rough rice the procedure used was either natural drying by rack hanging or mechanical drying with heated air $\left(40^{\circ} \mathrm{C}\right.$ for $\left.10 \mathrm{hr}\right)$.

Kidoguchi $^{3)}$ and Nishigaki') found that the natality of the young adults of the two weevils changed with the water content of the hulled rice grains kept at a constant temperature of $30^{\circ} \mathrm{C}$, whereas the average duration for the preimaginal period of the progeny did not vary much. In our experiment all the grains were conditioned beforehand in a controlled atmosphere at $23^{\circ} \mathrm{C}$ and $75 \%$ R.H. to maintain the water content of grains at about $15 \%{ }^{4-6)}$ during the experiment.

Approximately 700 grains per container were used; about $15 \times 1.2 \mathrm{~g}$ for rough rice, $15 \times 1.0 \mathrm{~g}$ for hulled rice, and $15 \times 0.87 \mathrm{~g}$ for polished rice. The containers used were $225 \mathrm{ml}$ mayonnaise bottles $(4.6 \mathrm{~cm}$ in diameter and $10 \mathrm{~cm}$ high) covered with a 40-mesh wire net $3 \mathrm{~cm}$ in diameter (Plate 4). Each culture vial initially was populated with 100 unsexed two-day-old adults. The number of survivors $\left(l_{x}\right)$ in each container was counted weekly. Two replications were made for each drying procedure used with rough rice and four were made for hulled and polished rice. The supply of food was renewed every 21 days. Each week the adults were transferred to another vial containing new food and were allowed to oviposit for one day. As the number of eggs deposited in a grain could not be counted easily, only the progeny that emerged 
a month later were counted as the index of productivity $\left(l_{x} b_{x}\right)$. For parent adults aged 1-10 weeks, the period of development from oviposition to adult emergence was calculated from the curve of adult emergence.

\section{RESULTS}

The $l_{x-c u r v e s}$ of $S$. zeamais and $S$. oryzae

The survivorship $\left(l_{x}\right)$ curves of adult $S$. zeamais are shown in Fig. 1-A. One half of the individuals died within 1 week when kept on rough rice dried naturally, within 3 weeks on rough rice dried mechanically, within 17 weeks on hulled rice, and within 21 weeks on polished rice. The longest periods of survival on each form of grain were $4,20,45$, and 55 weeks, respectively. The survivorship curves of $S$. oryzae are shown in Fig. 2-A. One half of the individuals maintained on rough rice dried naturally, rough rice dried mechanically, hulled rice, and polished rice died within $1,3,13$, and 17 weeks, respectively. The longest periods of survival were 13, 11, 30, and 31 weeks, for each form of grain.

The mean length of the adult life span of rice weevils varied with the kind of food given, wheat or maize, and the species in Birch's experiment ${ }^{2)} ; 18.9$ weeks on wheat and 21.8 weeks on maize for $S$. zeamais and 16.9 weeks on wheat and 26.1 weeks on maize for $S$. oryzae. In our research the length of adult life was longer for $S$. zeamais than for S. oryzae and was longer on polished rice than on hulled rice in both species. The life span for both species was greatly reduced on rough rice, especially

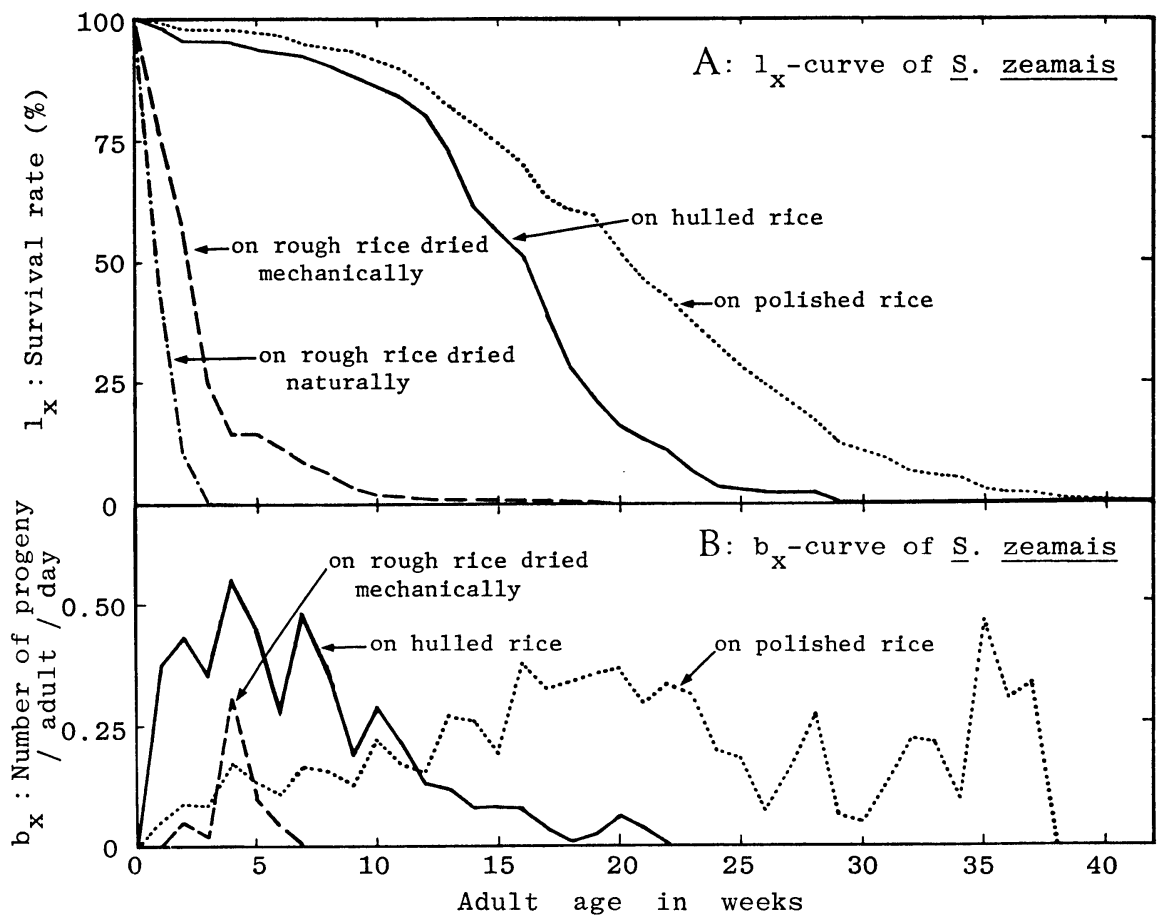

Fig. $1 l_{x}$-curves and $b_{x}$-curves for $S$. zeamais on different forms of rice grain. 


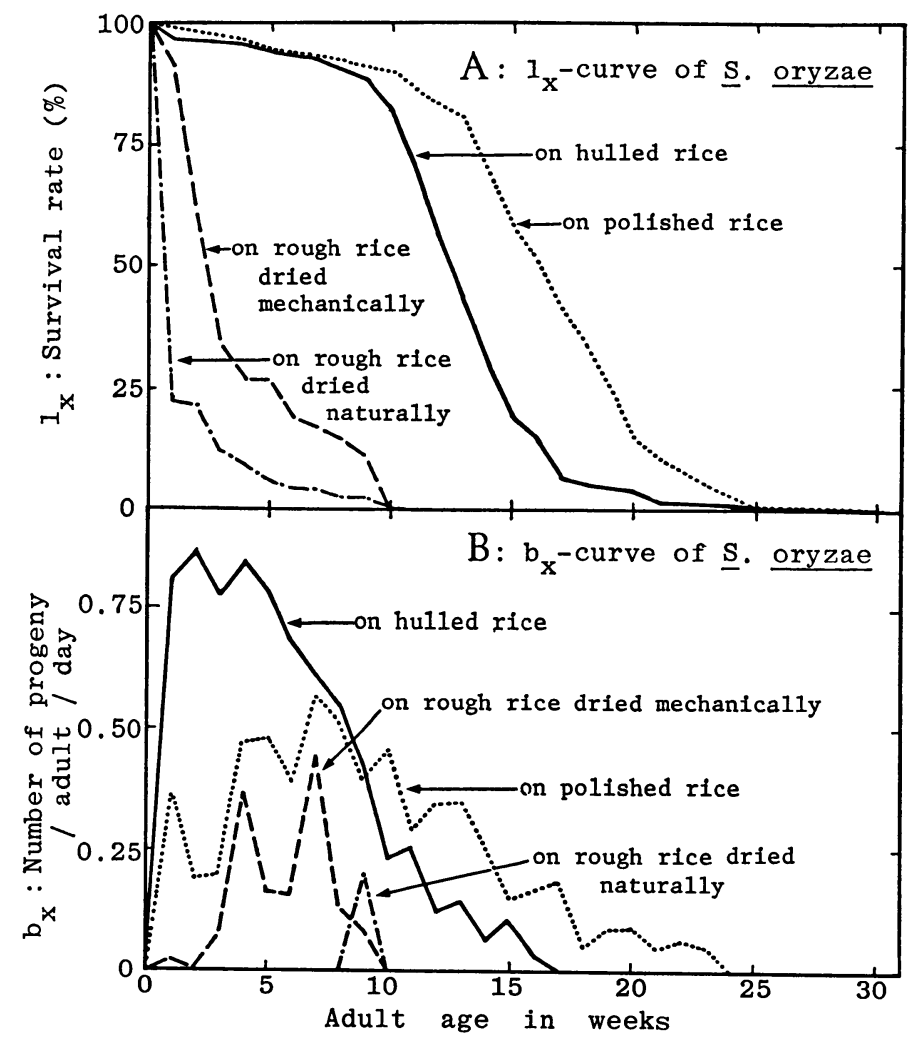

Fig. $2 l_{x}$-curves and $b_{x}$-curves for $S$. oryzae on different forms of rice grain.

on naturally dried rough rice.

\section{The $b_{x}$-curves of $S$. zeamais and S. oryzae}

On rough rice dried naturally no progeny of $S$. zeamais and only one individual of $S$. oryzae had emerged by the 9 th week. By contrast, eggs on mechanically dried rough rice produced some progeny. On hulled rice the number of progeny per adult $\left(b_{x}\right)$ of $S$. zeamais increased rapidly with adult aging up to a peak on the 4th week, then it decreased gradually. But, on polished rice it increased gradually and reached a maximum at the 20th week (Fig. 1-B). The period of oviposition lasted for 21 weeks on hulled rice and 37 weeks on polished rice. For S. oryzae, $b_{x}$ was high for weeks 1 to 5 , but declined steeply thereafter on hulled rice, whereas it reached at maximum on the 7th week then decreased gradually on polished rice (Fig. 2-B). The period of oviposition lasted for 17 weeks on hulled rice and 24 weeks on polished rice.

The $b_{x}$-curves of both species on wheat and maize in Birch's experiment ${ }^{2)}$ were similar to those for hulled rice in our study. But, the numbers of progeny at the peak of the $b_{x}$-curves for both species were much fewer in our experiment than in Birch's, and somewhat lower than the values for young adults determined 10-15 days after emergence in the experiments of Nishigaki ${ }^{4)}$ and Kidoguchi. ${ }^{3)}$ The reason for this discrepancy is not known, but the experimental procedures were differed somewhat 
Table 1 Average period of preimaginal development of Sitophilus zeamais and S. oryzae at $30^{\circ} \mathrm{C}, 70 \%$ R.H. The form of the rice grain was unhulled and mechanically dried, hulled, or polished.

\begin{tabular}{|c|c|c|c|c|c|c|c|c|c|}
\hline & \multicolumn{3}{|c|}{ Rough rice } & \multicolumn{3}{|c|}{ Hulled rice } & \multicolumn{3}{|c|}{ Polished rice } \\
\hline & $n$ & $\bar{x}$ & S.D. & $n$ & $\bar{x}$ & S.D. & $n$ & $\bar{x}$ & S.D. \\
\hline S. zeamais & 20 & 27.15 & 2.90 & 1411 & 23.73 & 2.24 & 506 & 27.72 & 3.25 \\
\hline S. oryzae & 64 & 31.11 & 3.21 & 2469 & 27.45 & 2.63 & 1529 & 31.63 & 3.43 \\
\hline
\end{tabular}

$n$ : number of individuals, $\bar{x}$ : mean duration, S.D. : standard deviation.

between studies. The results of our research for both species show greatly expanded $b_{x}$-curves on polished rice.

\section{Period of preimaginal development}

The interval between oviposition and adult emergence is shown in Table 1. It was shortest on hulled rice; 23.7 days for $S$. zeamais and 27.5 days for $S$. oryzae. The period on rough and polished rice was almost the same; 27 days for S. zeamais and 31 days for S. oryzae.

In Nishigaki's experiment ${ }^{4)}$ the interval on hulled rice with a $15.5 \%$ water content and at $30^{\circ} \mathrm{C}$ was 24.6 days for $S$. zeamais and 26.7 days for S. oryzae. His results were very similar to ours, but the interval between oviposition and emergence was longer on polished rice.

\section{DISCUSSION}

No difference was found in the percentage of germination on rough rice, mechanically dried with heated air and on naturally dried rough rice, but there were differences in the surface condition of the grain husks. Naturally dried grains showed very few splits in their husks, and very few weevils could reach penetrate the husk to feed and oviposit. Mechanical heating, however, produced splits in the husks which weevils were able to penetrate and deposit eggs (Plates 5 and 6). Adults of S. oryzae produced more progeny than $S$. zeamais on rough rice. The smaller size of $S$. oryzae allowed them to deposit more eggs through a split.

The developmental period was short on hulled rice compared to that on polished rice. For mechanically dried rough rice the period was longer than for hulled rice, whereas there were no nutritional differences between the unhulled and hulled rice. When part of the husk was torn off to make a wide split, there were no differences in the developmental period. The emergence of the weevils seemed to be inhibited by the rice husks; some dead weevils that could not escape were found inside the husk (Plate 7).

Hulled rice contains a much better balance of nutrients than polished rice and a higher content of minerals and vitamins. ${ }^{7)}$ The peak of the $b_{x}$-curve came earlier on hulled than on polished rice, but longevity was shorter on hulled rice. The better nutrients in hulled rice might accelerate the ovipositional development of adults while reducing longevity. The natality of weevils on polished rice increased with aging for several months. This may be because fungal flora developed on polished rice and thus improved nutritional conditions for the weevils. 

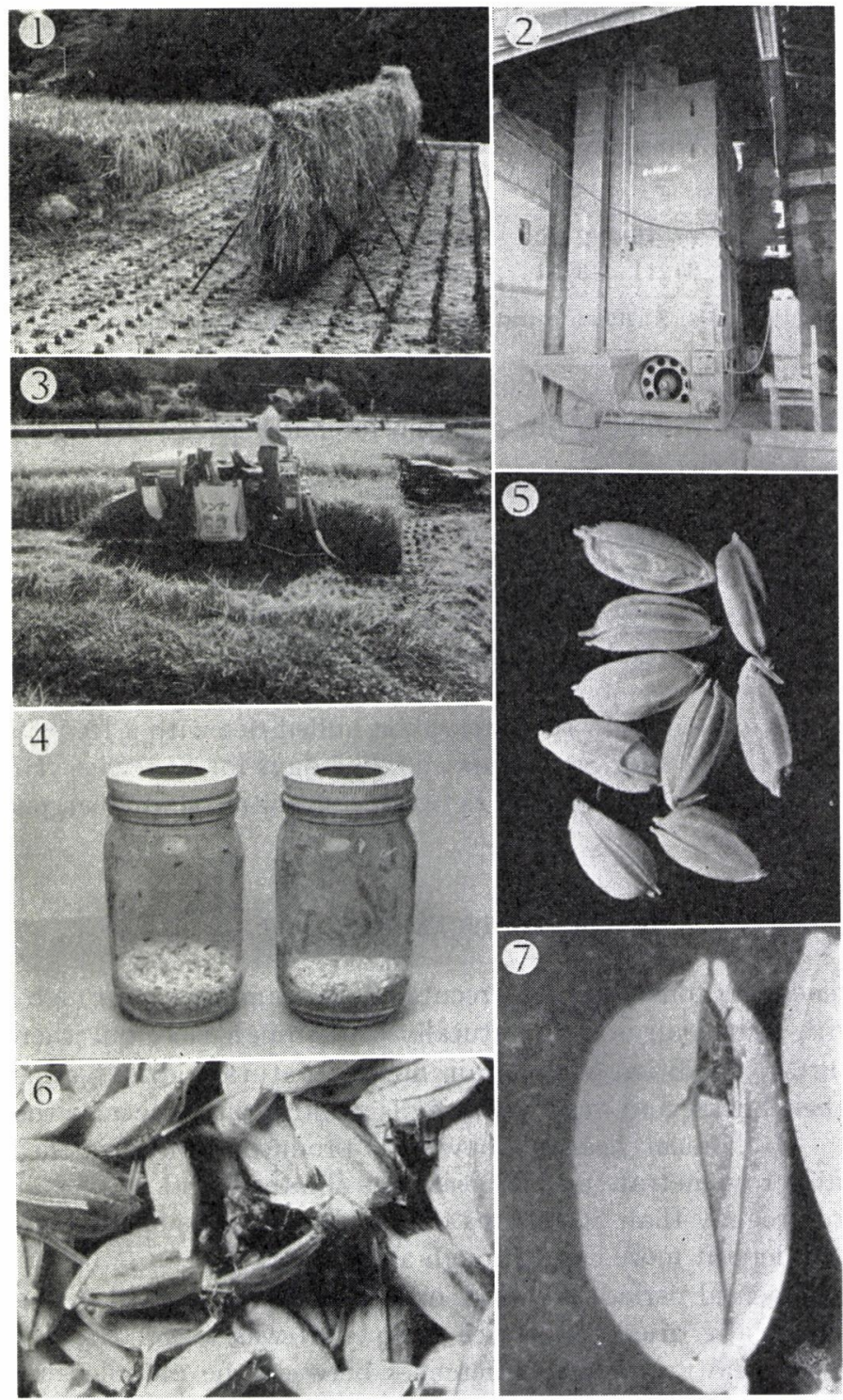

Plate 1 Drying of rice grain by hanging the harvested plants.

Plate 2 Mechanical dryer of rice grain.

Plate 3 Harvesting rice grain with a combine.

Plate 4 Rearing vial for rice weevils.

Plate 5 Broken husks of grain dried mechanically with heated air.

Plate 6 Aggregation of rice weevils in a few grains with splits in their husks.

Plate 7 A dead adult weevil which failed to emerge from a rough rice grain.

The values of $R_{t}\left(=\sum_{x=0}^{t} l_{x} b_{x}\right)$ changed with adult aging (Fig. 3). $R_{t}$ increased rapidly on hulled rice, then reached an asymptotic value on the 15 th week for both spe- 


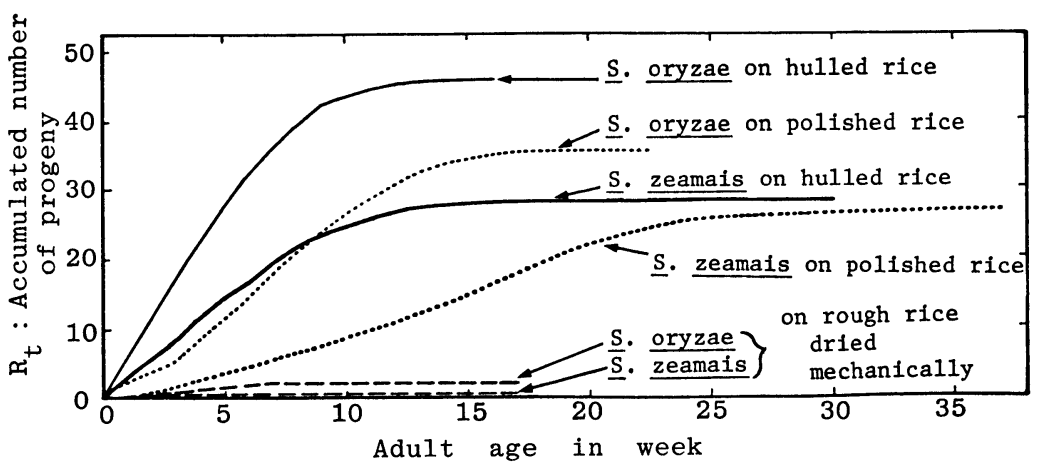

Fig. 3 Accumulated number of progeny produced with adult aging, $R_{t}=\sum_{x=0}^{t} l_{x} b_{x}$.

Table 2 Reproductive potential of Sitophilus zeamais and S. oryzae on different forms of rice grain at $30^{\circ} \mathrm{C}, 70 \%$ R.H. Rough rice was mechanically dried.

\begin{tabular}{llcccc}
\hline Form of & $\begin{array}{c}\text { Fet } \\
\text { rice grain }\end{array}$ & $\begin{array}{c}\text { Neproductive } \\
\text { power in one } \\
\text { generation } \\
\left(R_{0}\right)\end{array}$ & $\begin{array}{c}\text { Mean } \\
\text { length } \\
\text { of a } \\
\text { generation } \\
(T \text { week })\end{array}$ & $\begin{array}{c}\text { Innate } \\
\text { capacity for } \\
\text { increase } \\
\text { per week } \\
\left(v_{c}\right)\end{array}$ & $\begin{array}{c}\text { Finite } \\
\text { rate of } \\
\text { increase } \\
\text { per week } \\
(\lambda)\end{array}$ \\
\hline \multirow{5}{*}{ S. oryzae } & Rough rice & 0.70 & 7.48 & -0.048 & 0.953 \\
& Hulled rice & 28.42 & 9.48 & 0.353 & 1.423 \\
& Polished rice & 26.98 & 18.24 & 0.181 & 1.198 \\
\hline
\end{tabular}

cies. On polished rice, however, the increase of $R_{t}$ was retarded greatly, the asymptotic values being attained in the 25th week for $S$. zeamais and in the 20th week for $S$. oryzae. Finally the $R_{t}$ values became close for the hulled and polished rice with $S$. zeamais. The asymptotic value, $\sum_{x=0}^{\infty} l_{x} b_{x}$ is the net reproductive power in one generation, $R_{0}$. The value is lowest on rough rice (Table 2). In this case productivity was estimated within one generation, but population growth must be considered a combination of $R_{t}$ and developmental speed. In the equation for exponential population growth, $N_{t}=N_{0} e^{r t}$, in which $N_{t}$ is the number of individuals at time $t$, the rate of population growth, $r$, would show very different values for hulled and polished rice because the developmental speed was faster on hulled rice. The innate capacity for natural increase, $r_{c}=\ln R_{0} / T$, was calculated for which the mean length of a generation is $T=\sum x l_{x} b_{x} / \sum l_{x} b_{x}+$ the mean length of the preimaginal period. Results are shown in Table 2. The finite rate of increase per week, $\lambda=e^{r_{c}}$, also was calculated. For both species these values were highest on hulled rice followed by polished rice, rough rice having the lowest value. We thus conclude that rough rice is the best form of storage by which to protect rice grain from rice weevils, as was pointed out by Takahashi. ${ }^{1)}$ For a short period of storage, the polished form is somewhat better 
than the hulled form. The mechanical drying of rice grain with heated air provides a greater chance for weevils to infest the grain.

\section{REFERENCES}

1) Takahashi, S. 1931. “The Pests of Rice and Their Control” 43, Meibundo, Tokyo (in Japanese).

2) Birch, L. C. 1953. Experimental background to the study of the distribution and abundance of insects. 1. The influence of temperature, moisture, and food on the innate capacity for increase of three grain beetles. Ecology 34: 698-711.

3) Kidoguchi, J. 1978. Reproduction of maize and rice weevils on rough rice at various water contents. Jpn. J. Appl. Ent. Zool. 22: 207-209 (in Japanese with English summary).

4) Nishigaki, J. 1958. The effects of the water content of rice and the temperature on the development and the reproductive rate of the geographical strains of the two rice weevils, Calandra oryzae L. and C. sasakii TAkAhashi. Jpn. J. Appl. Ent. Zool. 2: 264-270 (in Japanese with English summary).

5) Harada, T. 1971. "The Biology and Control of Stored Product Insects" 141, Korinshoin, Tokyo (in Japanese).

6) Steffe, J. F., R. P. Singh, and G. E. Miller, Jr. 1980. Harvest, drying and storage of rough rice. In "Rice: Production and Utilization" (Ed. by Luh, B. S.) 311-359, AVI Publ. Co., Inc. Westport.

7) Sokoloff, A. 1974. "The Biology of Tribolium with Special Emphasis on Genetic Aspects" Vol. 2, 304, Clarendon Press, Oxford.

〈和文抄録〉

\section{収穫後の乾燥方法と精米過程での形状の異なる 米粒へのコクゾウ類の加害}

高橋史樹・水野博之

広島大学総合科学部環境科学研究科

米の収穫貯蔵時の乾燥条件と穀粒の形状は害虫の加害に大きく影響する．コクゾウとココクゾウの繁 殖と発育を $30^{\circ} \mathrm{C}, 70 \%$ R.H. の条件下で, 精米段階別（もみ, 玄米, および白米）と, もみ乾燥条件 別（はざ干しによる自然乾燥と, 温風による機械乾燥）に, 生命表を求めて比較した.

自然乾燥もみからは子世代成虫は生じなかった。機械乾燥もみでは，もみ外皮に生じた隙間から産卵 した。発育期間は玄米で最短となった．白米は栄養的に玄米より劣っているようである．成虫の生存期 間と産卵期間は白米において最長で，もみでは最短となった。繁殖能力は成虫の加齢とともに変化し た. 産卵数が最大となる時期は玄米では白米でよりも早かった。成虫生存期間中での繁殖能力は玄米で 最大となり，もみで最小となった。

これらの結果から，米穀の貯蔵中でのコクゾウ類の発生を防ぐにはもみ貯藏が最も望ましいといえ る. 